\title{
Classification Sensing Image of Remote Using Landsat 8 through Unsupervised Classification Technique (Case Study of Bangkalan Regency)
}

\author{
Rosida Vivin Nahari ${ }^{1}$, Riza Alfita ${ }^{2}$
}

Department of Engineering, Trunojoyo University, Indonesia

\begin{abstract}
Bangkalan regency is classified as a new regency which is located East Java, Indonesia. This regency possesses several potential areas in agriculture, plantation, and fishery. This research employs image analysis process of remote sensing satellite Landsat 8 in Bangkalan regency. This research uses Landsat 8 satellite image processing method from image data collection stage to classification stage by using unsupervised classification technique. This method produces land appearance, such as agriculture, ponds, and settlements in Bangkalan regency. This research classification result can be used as a reference of vegetation coverage in Bangkalan regency. Based on the research result, rice field vegetation is very dominant compared to other areas in Bangkalan Regency. Rice field vegetation coverage is much more dominant than other coverage such as residential area. The main objective of this study is to obtain the scale of comparison or area percentage in Bangkalan.
\end{abstract}

Keywords - Landsat 8, remote sensing, unsupervised classification

\section{INTRODUCTION}

One of the districts in East Java is Bangkalan regency which is geographically located in the westernmost part of Madura Island. Bangkalan Regency possess an area of $1,260.14 \mathrm{~km} 2$ is located between $112^{\circ} 40$ '06 "- $113^{\circ} 08^{\prime}$ 04" East Longitude and 6 51 '39 "- $7^{\circ} 11^{\prime}$ '39" South Latitude. The Regency is adjacent to Sampang Regency in the east, Madura Strait / Gresik Regency in the west, the Java Sea in the north and Madura Strait / Surabaya City in the south. Bangkalan Regency administratively consists of 18 districts, 273 villages and 8 hamlets.

Bangkalan is located at one end of Madura island. It is a very profitable location because it is adjacent to Surabaya city which is a trading center in East Java. Bangkalan Regency is a development area of Kertasusila Gate and is included in Surabaya City Development or better known as Surabaya Urban Development Policy. With the construction of the Suramadu bridge connecting the land routes between Surabaya and Bangkalan as well as the international seaports and container terminals, Bangkalan possesses positive impact on economic development especially investment in Bangkalan Regency.

The agricultural sector plays an important role in Bangkalan regency development. Leading commodities was acquired from food crops such as rice, corn, cassava, peanuts, sweet potatoes, soybeans, and green beans. Potential production of horticultural crops is also quite prominent. These include fruits, vegetables, and medicinal plants. This regency possesses the potential for planting superior commodities or crops such as coconut, cashew nut, kapok, and areca nut.

Bangkalan regency is one of rice producing districts in East Java. BPS Bangkalan regency notes that rice production in Bangkalan regency in 2013 is 132,901 Tonnes. In addition, BPS also noted that in 2015 the population of Bangkalan Regency is 954.305 people with growth rate $2014-2015$ of $0.9 \%$ per year (BPS East Java, 2015).

Based on BPS data, Bangkalan District outline condition was observed. To ensure the geographical monitoring of the area, satellite images data processing were taken directly from Landsat 8 using remote sensing method. The method produced geographical vegetation appearance. Landsat 8 satellite image data processing utilized Unsupervised Classification technique, which aims to classify division of element classes or t land cover types such as; Urban, water bodies, wetlands, etc. This method had obtained how land cover types in the concerned area. Wiradisastra and Noviar stated that satellite image data processing accuracy depends on respective reviewed region's field condition, area, and characteristics (Wiradisastra \& Noviar, 2005).

Another study stated image processing analysis accuracy is supported by the amount of cloud covering a study area (Hanindito, Tanaamah, \& Papilaya, 2010).

Remote sensing is the science of observing and gathering information regarding objects on earth's surface, using certain sensors, without direct contact with the observed objects (Andree Ekadinata, Sonya Dewi, Danan Prasetyo Hadi, Dudy Kurnia Nugroho, 2008). 


\section{RESEARCH METHOD}

The following Figure 1 describes research stages.

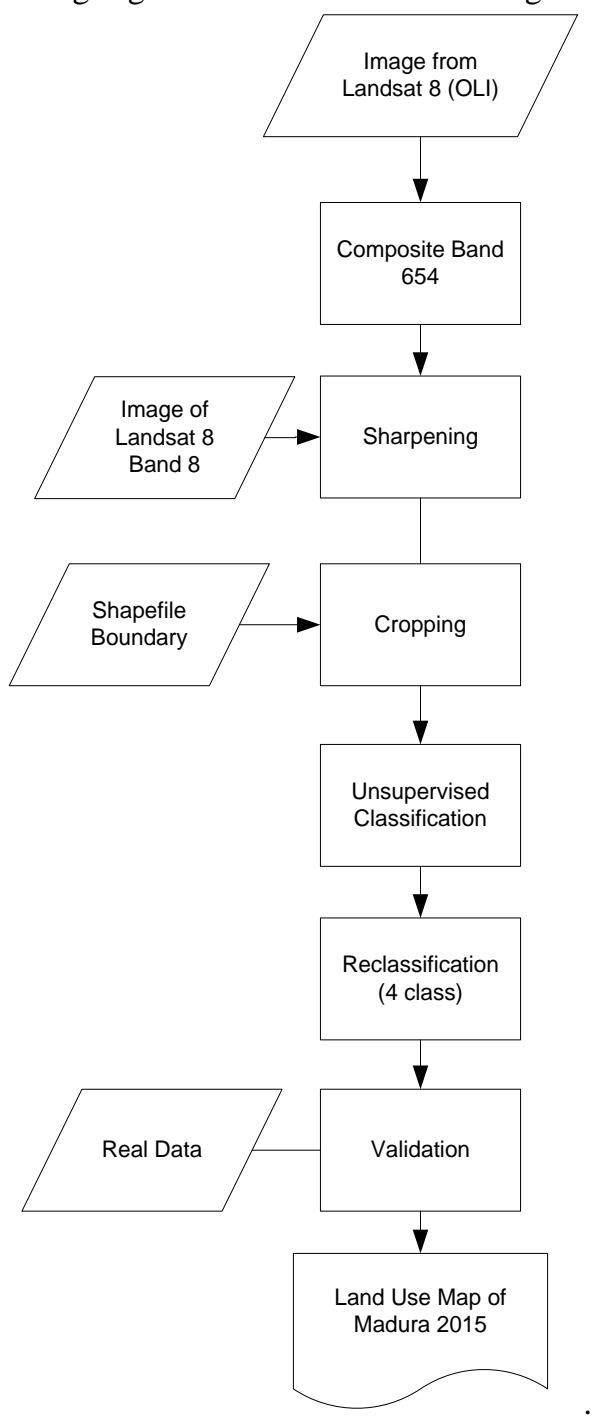

Fig. 1: Research Stage Chart

\subsection{Image Conversion}

Downloaded Landsat 8 satellite image is satellite images consisting of multiple bands of satellite sensor recordings. The image is are in* tiff file extension and cannot be analyzed. Therefore image conversion was conducted to facilitate analysis process. The conversion was conducted by combining between several bands of an image in an appearance with $*$ file extension.

The following is a list of $R$ G B sequences of band combinations in the available Landsat 8 Satellite Imagery:

Table.1: band combinations in the available Landsat 8

\begin{tabular}{|c|c|}
\hline $\begin{array}{c}\text { BAND } \\
\text { COMBINATI } \\
\text { ON }\end{array}$ & FUNCTION / \\
\hline $\begin{array}{c}\text { Natural Color } \\
-432\end{array}$ & Produce an image with true color \\
\hline False Color & Produce images with distinct \\
\hline
\end{tabular}

\begin{tabular}{|c|c|}
\hline $\begin{array}{l}\text { (urban)- } \\
764\end{array}$ & differences in urban areas \\
\hline $\begin{array}{l}\text { Color Infrared } \\
\text { (vegetation) - } \\
543\end{array}$ & $\begin{array}{l}\text { Used to see the mass, density, and } \\
\text { dominance of vegetation. The contrast } \\
\text { between vegetation dominance will be } \\
\text { seen in infrared, making it effective for } \\
\text { large-scale forestry or agricultural } \\
\text { vegetation analyzes }\end{array}$ \\
\hline $\begin{array}{l}\text { Agriculture - } \\
652\end{array}$ & $\begin{array}{l}\text { Produce an image with distinct } \\
\text { vegetation indicated by greenish color }\end{array}$ \\
\hline $\begin{array}{l}\text { Atmospheric } \\
\text { Penetration - } \\
765\end{array}$ & $\begin{array}{l}\text { Clarify the image of cloud thickness, } \\
\text { clarify shoreline, and vegetation cover. } \\
\text { This combination can clarify the image } \\
\text { from weather disturbance }\end{array}$ \\
\hline $\begin{array}{l}\text { Healthy } \\
\text { Vegetation - } \\
562\end{array}$ & $\begin{array}{l}\text { Produce an image that reveals healthy } \\
\text { vegetation }\end{array}$ \\
\hline $\begin{array}{l}\text { Land/Water - } \\
564\end{array}$ & $\begin{array}{l}\text { Produces images with distinct } \\
\text { differences on water and land regions. }\end{array}$ \\
\hline $\begin{array}{l}\text { Natural With } \\
\text { Atmospheric } \\
\text { Removal - } \\
753\end{array}$ & $\begin{array}{l}\text { Produce images with natural colors and } \\
\text { reduce the appearance of clouds }\end{array}$ \\
\hline $\begin{array}{l}\text { Shortwave } \\
\text { Infrared - } \\
754\end{array}$ & $\begin{array}{l}\text { To get the biomass with clear contrast } \\
\text { and cleaner images of cloud cover }\end{array}$ \\
\hline $\begin{array}{l}\text { Vegetation } \\
\text { Analysis - } \\
654\end{array}$ & Used to analyze plants \\
\hline
\end{tabular}

This study utilized Landsat satellite images RGB 654 composites. Three bands included were near-infrared and visible spectra. These have wavelengths corresponded to 4, 5 and 3 bands wavelengths on satellite images Landsat $7 \mathrm{ETM}+$.

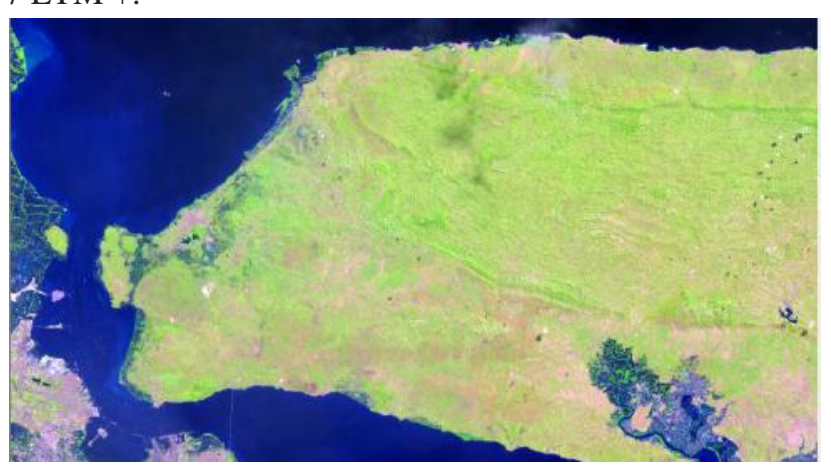

Fig. 2:band 6, band 5 and band 4 combination

\subsection{Image Contrast Improvement}

This process is done in order to obtain images possessing color quality similar to the original appearance on the earth surface and support the following image classification process. This process is aimed at providing a sharper coloring in an endeavor in enabling easier image 
classification process. Figure 3 illustrates the process of improving image contrast.

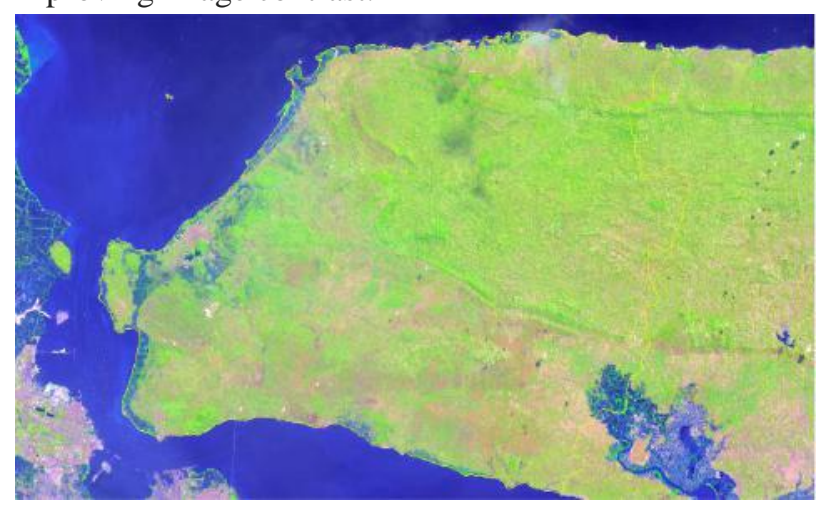

Fig. 3: raster data and vector data

\subsection{Image Cropping}

Process on cropping study area images is conducted on this stage. This process aims to facilitate the analysis process by focusing study area by eliminating regions unused in research. This process was conducted by combining raster data (satellite image data) with data vector which is administrative data of Bangkalan Regency borders.

\subsection{Image Classification}

This process is a review of image appearance based on the visible phenomenon. The image is generated and analyzed using true color composite terminology or image appearance in accordance with its original appearance on earth surface. Classification process was conducted by distinguishing each color contained in the image. Figure 5 illustrations will illustrate the appearance of satellite imagery and its classification.

\section{RESULTS AND DISCUSSION}

This research produces categorized images, and determined vegetation classification contained in Bangkalan Regency, East Java. Figure 6 exhibits Landsat 8 satellite image data processing classification.

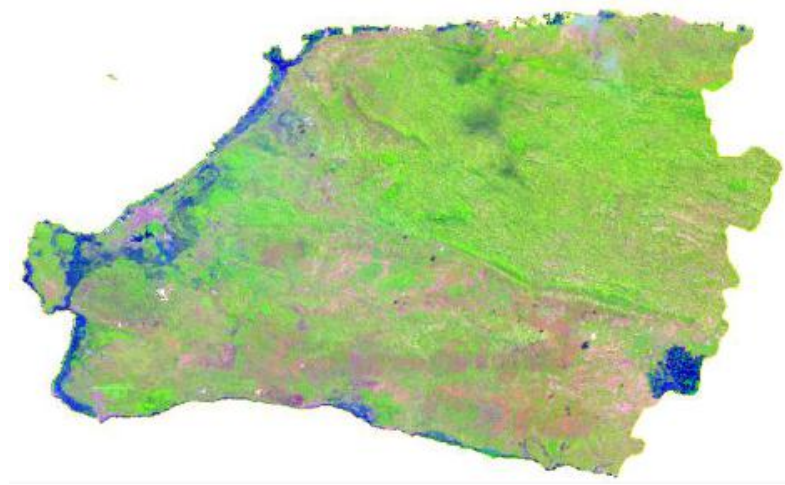

Fig. 4: image cropping results

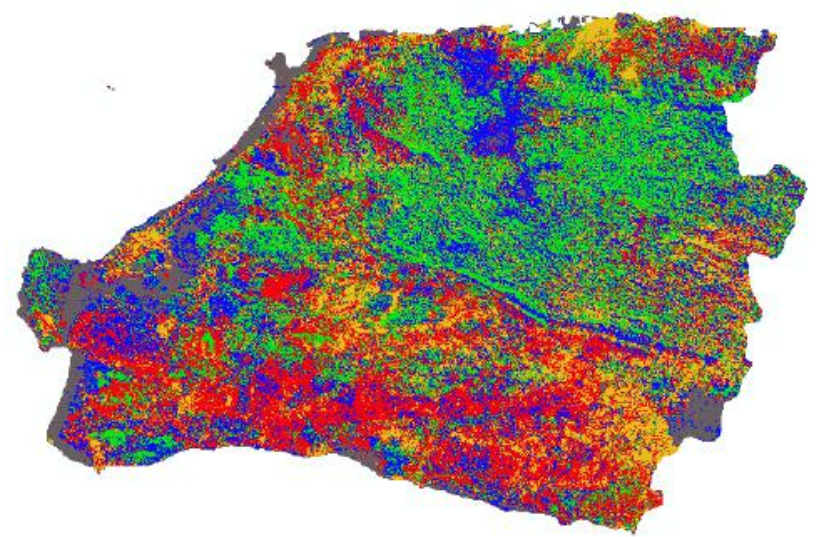

Fig. 5: analysis of unsupervised classification image imagery

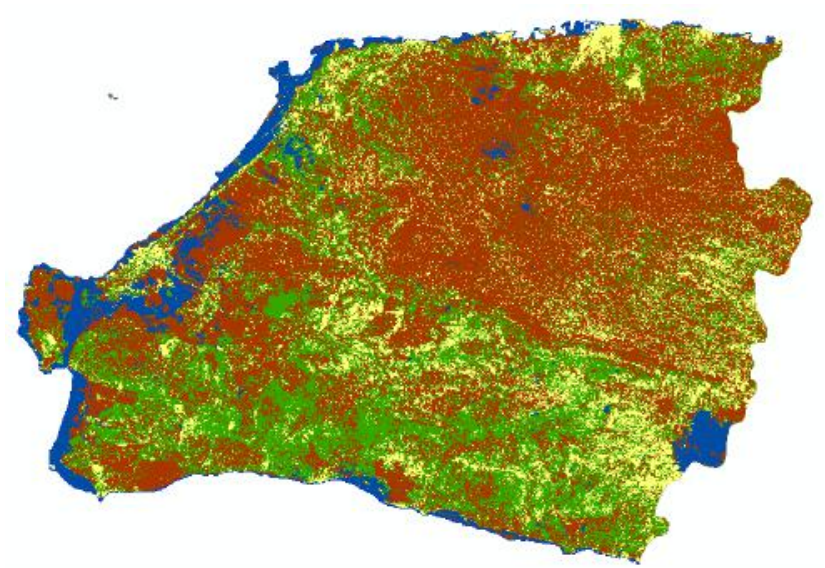

Fig. 6: map of reclassification validation results

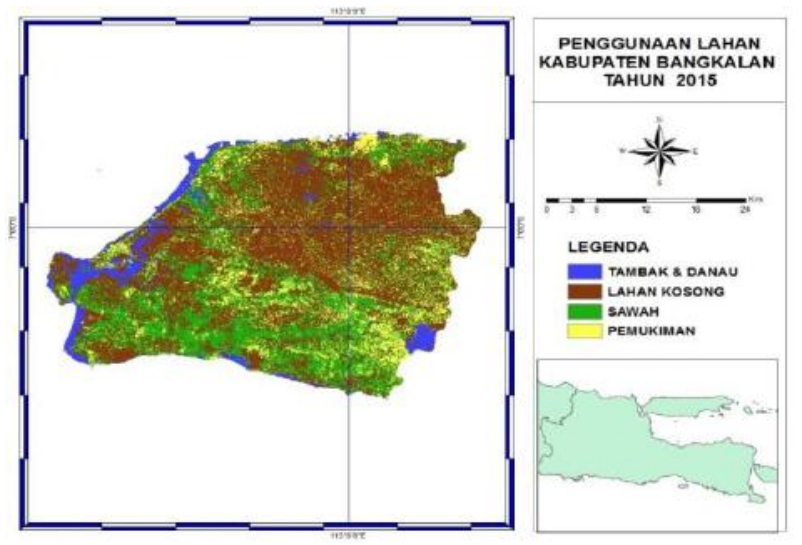

Fig. 7: image classification legends

Forest vegetation is dominant in Bangkalan Regency. Based on image classification, Bangkalan district is dominated by rice field area, with small regions of housings. Followed by several other imagery appearances. The following table exhibit Bangkalan Regency's Landsat 8 satellite image classification analysis and graphs on the landscape appearance. 
Table.2: Landscape Appearance of Area Percentage Classification Result

\begin{tabular}{|l|l|l|}
\hline No & Image & Total Area Percentage \\
\hline 1 & Dyke \& Lake & 6.106448 \\
\hline 2 & Farming & 51.301141 \\
\hline 3 & Vacant & 28.38344 \\
\hline 4 & Housing & 14.208971 \\
\hline
\end{tabular}

\section{PERCENTAGE OF AREA}

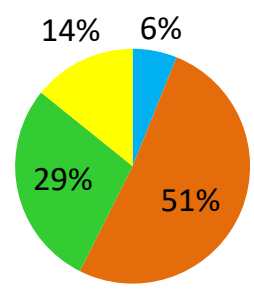

- Tambak

Lahan

Kosong

- Sawah

Fig. 8: Bangkalan Regency Land Acquisition Percentage Graph

\section{CONCLUSION}

Based on Landsat 8 satellite image observation, almost every Bangkalan district consists of vacant land. This exhibits land untouched by human hands to be processed into productive land such as plantation and agricultural land clearing. Satellite images were taken on June 16, 2015. It is suggested for future research to compare the results of previous year's image analysis, to find out the extent agricultural land area extension by utilizing vacant land empowerment.

\section{REFERENCES}

[1] Alonso, W. (1964). Location and land use. Toward a general theory of land rent. Location and land use. Toward a general theory of land rent.

[2] Cohen, W. B., Fiorella, M., Gray, J., Helmer, E., \& Anderson, K. (1998). An efficient and accurate method for mapping forest clearcuts in the Pacific Northwest using Landsat imagery. Photogrammetric engineering and remote sensing, 64(4), 293-299.

[3] Hanindito, G. A., Tanaamah, A. R., \& Papilaya, F. S. (2010). Pengolahan Data Citra Satelit Landsat TM Dalam Pemantauan Area Kebakaran Hutan Berbasis GIS (Studi Area Kecamatan Arut Utara dan Seruyan Tengah, Propinsi Kalimantan Tengah).Universitas Kristen Satya Wacana.

[4] Turner, B. L., \& Meyer, W. B. (1991). Land use and land cover in global environmental change: considerations for study. International Social Science Journal, 43(130), 669-679.
[5] Statistik, B. P. (2015). Statistik kesejahteraan rakyat. Biro Pusat Statistik.

[6] Wiradisastra, \& Noviar, H.( 2005).Kemampuan Interpretasi Kebun Semangka Dari Citra Satelit Landsat-7 ETM+. Pertemuan Ilmiah Tahunan MAPIN XIV, (September), 132-140.

[7] Andree Ekadinata, Sonya Dewi, Danan Prasetyo Hadi, Dudy Kurnia Nugroho, F. J. (2008). Sistem Informasi Geografis Untuk Pengelolaan Bentang Lahan Berbasis Sumber Daya Alam. (1st ed., p. 70) Bogor.

[8] Lindeijer, E. (2000). Review of land use impact methodologies. Journal of Cleaner Production, 8(4), 273-281.

[9] Lillesand, T., Kiefer, R. W., \& Chipman, J. (2014). Remote sensing and image interpretation. John Wiley \& Sons.

[10] Woodcock, C. E., Allen, R., Anderson, M., Belward, A., Bindschadler, R., Cohen, W., ... \& Nemani, R. (2008). Free access to Landsat imagery. 